\title{
Yttrium Y 90 Anti-CD19 Monoclonal Antibody BU12
}

National Cancer Institute

\section{Source}

National Cancer Institute. Yttrium Y 90 Anti-CD19 Monoclonal Antibody BU12. NCI

Thesaurus. Code C74092.

A radioimmunoconjugate consisting of the murine IgG1 anti-CD19 monoclonal antibody (MoAb) BU12 labeled with the beta-emitting radioisotope yttrium Y 90 with radioisotopic and antibody activities. Yttrium Y 90 anti-CD19 monoclonal antibody BU12 binds to the CD19 molecule, specifically delivering cytotoxic beta radiation to CD19-expressing B cells. CD19 is a membrane antigen that is widely expressed during B-cell development, from pro-B-cell to early plasma cell stages. 